\title{
Hemoglobin Level Decrease after Open Heart Surgery in A Tertiary Hospital in Indonesia
}

\author{
Anabella Nifulea, ${ }^{1}$ Reza Widianto Sudjud, ${ }^{2}$ Rama Nusjirwan ${ }^{3}$ \\ ${ }^{1}$ Faculty of Medicine Universitas Padjadjaran, Indonesia, ${ }^{2}$ Department of Anesthesiology and \\ Intensive Care Faculty of Medicine Universitas Padjadjaran/Dr. Hasan Sadikin General Hospital \\ Bandung, Indonesia, ${ }^{3}$ Department of Thoracic and Vascular Surgery Faculty of Medicine \\ Universitas Padjadjaran/Dr. Hasan Sadikin General Hospital Bandung, Indonesia
}

\section{Abstract}

Background: Open heart surgery is usually performed by connecting the heart to a cardiopulmonary bypass (CPB) machine. The use of the CPB machine may decrease the hemoglobin level and a very low hemoglobin levelcould cause serious complications. This study aimed to explore the decrease in hemoglobin level after open heart surgery.

Methods: A cross-sectional retrospective descriptive study was conducted on medical records of patients underwent coronary artery bypass graft (CABG) surgery and heart valve surgery in a tertiary hospital in Indonesia in 2018. The total sampling method was deployed to all medical records of patients underwent CABG surgery $(n=25)$ and patients underwent heart valve surgery $(n=3)$.

Results: The decrease in hemoglobin level among young-adult female patients after heart valve surgery was $6.8 \mathrm{~g} / \mathrm{dl}$. The average decrease in mid-adult male and female patients after CABG surgery were 6 $\mathrm{g} / \mathrm{dl}$ and $5.8 \mathrm{~g} / \mathrm{dl}$, respectively, and, after the heart valve surgery, the levels were $8.5 \mathrm{~g} / \mathrm{dl}$ and $5.4 \mathrm{~g} / \mathrm{dl}$, respectively. The average decrease in $\mathrm{Hb}$ level among late-adult male and female patients after CABG surgery was $6.1 \mathrm{~g} / \mathrm{dl}$ and $5.4 \mathrm{~g} / \mathrm{dl}$, respectively.

Conclusions: Hemoglobin level decreases after an open heart surgery. Therefore, observation on the hemoglobin level to prevent complications and to facilitate early treatment is necessary.

Keywords: Coronary artery bypass graft surgery, heart valve surgery, hemoglobin

\section{Introduction}

Cardiovascular disease is the number one cause of death in the world. Estimated that 17.9 million people died of cardiovascular disease in 2016, representing 31\% of all deaths in the world. ${ }^{1}$ With heart disease as the number one killer in the world, there are a lot of treatments carried out to prevent death. One of them is open-heart surgery. ${ }^{2}$ Open heart surgery is usually conducted by connecting the heart to the cardiopulmonary bypass (CPB) machine. ${ }^{3}$ The most common open-heart surgeries are coronary artery bypass graft (CABG) surgery and heart valve surgery., 4

The use of CPB machines will cause hemodilution. Hemodilution occurs due to the process of mixing the blood of patients with priming fluid in the extracorporeal circuit. ${ }^{6}$ Hemodilution will cause a decrease in hemoglobin (Hb) levels. ${ }^{7}$ Besides hemodilution, hemolysis can also cause a decrease in hemoglobin levels. Hemolysis is the damage of the red blood cell membrane integrity, causing the hemoglobin released and its levels fall. ${ }^{8}$ Hemolysis during openheart surgery might also be caused by the use of CPB machines. ${ }^{9}$ Several things can cause hemolysis; the first cause is trauma due to $\mathrm{CPB}$ engine pumps caused by high shear stress. The second cause is an augmented or assisted venous return (AVD). The third cause is the arterial cannula. ${ }^{10-12}$ Excessive decreased in hemoglobin levels can cause serious complications such as dyspnea, hypotension, tachycardia, and loss of consciousness. ${ }^{13}$

The aim of the study was to explore the decrease of hemoglobin levels after openheart surgery. It is expected that the result might give information for clinicians to

Correspondence: Anabella Nifulea, Faculty of Medicine, Universitas Padjadjaran, Jalan Raya Bandung Sumedang Km. 21 Jatinangor, Sumedang Indonesia, Email: beanifulea@yahoo.com 
Table 1 Characteristics of Patients Underwent Open Heart Surgery

\begin{tabular}{|c|c|c|c|c|c|c|c|c|}
\hline \multirow{2}{*}{ Age Groups } & \multicolumn{4}{|c|}{ CABG Surgery $(n=25)$} & \multicolumn{4}{|c|}{ Heart Valve Surgery $(n=3)$} \\
\hline & Male & Female & $\mathbf{N}$ & $\%$ & Male & Female & $\mathbf{N}$ & $\%$ \\
\hline $\begin{array}{l}\text { Young Adult } \\
\text { (18-35 years old) }\end{array}$ & 0 & 0 & 0 & 0 & 0 & 1 & 1 & 33.3 \\
\hline $\begin{array}{l}\text { Middle Adult } \\
\text { (36-55 years old) }\end{array}$ & 8 & 1 & 9 & 36 & 1 & 1 & 2 & 66.7 \\
\hline $\begin{array}{l}\text { Late Adult } \\
(>55 \text { years old })\end{array}$ & 14 & 2 & 16 & 64 & 0 & 0 & 0 & 0 \\
\hline Total & 22 & 3 & 25 & 100 & 1 & 2 & 3 & 100 \\
\hline
\end{tabular}

Note: $\mathrm{CABG}=$ Coronary Artery Bypass Graft

prevent the decrease of Hb levels during openheart surgery.

\section{Methods}

This study was a retrospective descriptive study with a cross-sectional design, conducted from June to November 2019 using secondary data from the medical record database in Dr. Hasan Sadikin General Hospital, Bandung. All data of the patients aged $\geq 18$ years old who underwent $\mathrm{CABG}$ and heart valve surgery in 2018 were collected. Only data with complete medical records were included. The exclusion criteria were incomplete data on $\mathrm{Hb}$ values before and after CABG or heart valve surgery. Those who had low Hb levels before CABG and heart valve surgery were also excluded. The normal $\mathrm{Hb}$ value of adult men was 13.5$18 \mathrm{~g} / \mathrm{dl}$ and of adult women was 12-15 g/ dl. ${ }^{14}$ Data collection was carried out after obtaining ethical approval number 955/ UN6.KEP/EC/2019 issued by the Research
Ethics Committee of Universitas Padjajaran, and Research Licensing Letter issued by the Research Ethics Committee of Dr. Hasan Sadikin General Hospital Bandung (No. LB.02.01/X.2.2.1/1781/2019). The selected data was analyzed and presented in a table to illustrate the decrease of hemoglobin levels.

\section{Results}

In total, data were collected from CABG surgery patients $(n=25)$ and heart valve surgery patients $(n=3)$. The characteristic of the patients was shown in Table 1 . There were no young adult patients who underwent CABG surgery, and there were no late adult patients who underwent heart valve surgery. The majority of CABG surgery patients were in the late adult group (64\%) and male (88\%) patients, whereas, the majority of heart valve surgery patients were in the middle adult group $(66.7 \%)$ and female patients $(66.7 \%)$.

The decrease of hemoglobin levels after

Table 2 Decrease of Hemoglobin Levels After Open Heart Surgery Based on Age Groups and Gender

\begin{tabular}{|c|c|c|c|c|c|c|c|}
\hline \multirow[b]{2}{*}{ Age Groups } & \multirow[b]{2}{*}{ Gender } & \multicolumn{3}{|c|}{ CABG } & \multicolumn{3}{|c|}{ Heart Valve } \\
\hline & & $\begin{array}{c}\overline{\mathbf{x}} \mathbf{H b} \\
\text { Preoperative } \\
\text { (g/dl) }\end{array}$ & $\begin{array}{c}\overline{\mathbf{x}} \mathbf{H b} \\
\text { Postoperative } \\
\text { (g/dl) }\end{array}$ & $\begin{array}{c}\sqrt{A} \\
\text { Decrease } \\
\text { Hb Levels } \\
\text { (g/dl) }\end{array}$ & $\begin{array}{c}\overline{\mathbf{x}} \\
\text { Hb } \\
\text { Preoperative } \\
\text { (g/dl) }\end{array}$ & $\begin{array}{c}\overline{\mathbf{x}} \\
\text { Hb } \\
\text { Postoperative } \\
\text { (g/dl) }\end{array}$ & $\begin{array}{c}\qquad 1 \\
\text { Decrease } \\
\text { Hb Levels } \\
\text { (g/dl) }\end{array}$ \\
\hline Young Adult & Male & - & - & - & - & - & - \\
\hline (18-35 years old) & Female & - & - & - & 13.6 & 6.8 & 6.8 \\
\hline Middle Adult & Male & 15.2 & 9.2 & 6 & 15.6 & 7.1 & 8.5 \\
\hline (35-55 years old) & Female & 13.3 & 7.5 & 5.8 & 13.9 & 8.5 & 5.4 \\
\hline Late Adult & Male & 14.9 & 8.8 & 6.1 & - & - & - \\
\hline (>55 years old) & Female & 12.9 & 7.5 & 5.4 & - & - & - \\
\hline
\end{tabular}

Note: CABG, Coronary Artery Bypass Graft 
Table 3 Packed Red Blood Cell Transfusion Given After Open Heart Surgery Based on Age Groups and Gender

\begin{tabular}{|c|c|c|c|c|c|c|c|}
\hline & \multicolumn{2}{|c|}{$\begin{array}{c}\text { Young Adult } \\
\text { (18-35 years old) }\end{array}$} & \multicolumn{2}{|c|}{$\begin{array}{c}\text { Middle Adult } \\
\text { (35-55 years old) }\end{array}$} & \multicolumn{2}{|c|}{$\begin{array}{c}\text { Late Adult } \\
(>55 \text { years old })\end{array}$} \\
\hline & & Male & Female & Male & Female & Male & Female \\
\hline \multirow{2}{*}{$\overline{\mathrm{x}} \mathrm{PRBC}(\mathrm{ml})$} & CABG & - & - & 490.5 & 894 & 531.1 & 457.5 \\
\hline & Heart Valve & - & 385 & 525 & 183 & - & - \\
\hline
\end{tabular}

Note: $\mathrm{CABG}=$ Coronary Artery Bypass Graft; PRBC= Packed Red Blood Cell

open-heart surgery based on age groups and gender were shown in Table 2. Data from the female patient showed preoperative $\mathrm{Hb}$ was $13.6 \mathrm{~g} / \mathrm{dl}$, and postoperative $\mathrm{Hb}$ was $6.8 \mathrm{~g} / \mathrm{dl}$. There was a significant decrease of $\mathrm{Hb}$ levels up to $50 \%$. In the middle adult group (36 55 years old), the decrease of $\mathrm{Hb}$ levels in male patients and female patients after CABG surgery was $6 \mathrm{~g} / \mathrm{dl}$ and $5.8 \mathrm{~g} / \mathrm{dl}$, respectively. The decrease of $\mathrm{Hb}$ levels in male patients and female patients after heart valve surgery was $8.5 \mathrm{~g} / \mathrm{dl}$ and $5.4 \mathrm{~g} / \mathrm{dl}$, respectively. The average decrease of $\mathrm{Hb}$ levels in male patients after CABG surgery was $6.1 \mathrm{~g} / \mathrm{dl}$, and in female patients was $5.4 \mathrm{~g} / \mathrm{dl}$.

Table 3 showed the number of packed red blood cell (PRBC) transfusion after open-heart surgery, based on age groups and gender. In the middle adult group, the average PRBC transfusion in male and female patients after CABG surgery was $490.5 \mathrm{ml}$ and $894 \mathrm{ml}$, respectively, whereas the administration of PRBC transfusion in male and female patients after heart valve surgery was $525 \mathrm{ml}$ and $183 \mathrm{ml}$, respectively. In the late adult group, the average number of PRBC transfusions received by male and female patients after CABG surgery was $531.1 \mathrm{ml}$ and $457.5 \mathrm{ml}$, respectively.

\section{Discussion}

The result of this study showed that patients of CABG surgery were predominantly male (88\%), conform the other study showing that men have a higher risk of coronary heart disease than women. ${ }^{15}$ Men have a higher risk of coronary heart disease because men smoke more and have higher alcohol consumption than women. ${ }^{16}$ Men also have a higher risk of heart valve disease than women. ${ }^{17}$ However, our study shows that there is a trend that female was more prevalent than men, although the numbers of patients are very limited.

Furthermore, the age of patients who underwent of CABG surgery in this study are predominantly (64\%) the late adult group ( $>55$ years old). This data is similar to data from the Ministry of Health Republic of Indonesia. ${ }^{18}$ As for patients with heart valve surgery in this study, the middle adult group (36-55 years old) was predominant (66.7\%).

In this study, the average decrease of hemoglobin levels in male and female patients of the middle adult group after CABG surgery is $6 \mathrm{~g} / \mathrm{dl}$ and $5.8 \mathrm{~g} / \mathrm{dl}$, and after heart valve surgery is $8.5 \mathrm{~g} / \mathrm{dl}$ and $5.4 \mathrm{~g} / \mathrm{dl}$ respectively. Furthermore, the average decrease of hemoglobin levels in male and female patients of late adult group after CABG surgery is $6.1 \mathrm{~g} /$ $\mathrm{dl}$ and $5.4 \mathrm{~g} / \mathrm{dl}$. The decrease of hemoglobin is almost $50 \%$ of the baseline of hemoglobin before surgery. The decrease of hemoglobin levels in male patients is greater than female patients after CABG surgery and after heart valve surgery. The result of this study is similar to a study that examined the decrease of hemoglobin levels after cardiac surgery in Dhaka, Bangladesh. ${ }^{19}$ The monitoring of the hemoglobin in that study was taken on the 1st, $3^{\text {rd }}$, and $7^{\text {th }}$ post-operative days. Interestingly, the decrease of hemoglobin levels can be caused by hemolysis and hemodilution due to the use of CPB machines. ${ }^{6-9}$ Further study is needed to find out the factors that cause the difference in the decrease of hemoglobin levels.

In this study, all patients have received PRBC transfusion after CABG surgery and heart valve surgery. The purpose of PRBC transfusion is to prevent tissue hypoxia related to anemia. ${ }^{20}$ As a standard procedure, PRBC transfusion will be given after heart surgery when hemoglobin levels reach the transfusion threshold $\leq 7 \mathrm{~g} / \mathrm{dl}^{13}{ }^{13}$ In this study, all patients received PRBC transfusion even though some of the decreases in hemoglobin levels have not yet reached the threshold of PRBC transfusion. Further research is needed to find out the factors that influence this result.

There are some limitations to this study. The hemoglobin monitoring has been only 
conducted in the same day after the surgery. Hemoglobin level needs to be monitored regularly. Furthermore, the complete medical records before and after open-heart surgery needs to be well recorded. More patients' data analysis needs to be performed to have a good view on the hemoglobin decrease after open heart surgery.

In conclusion, the hemoglobin level is decreased after open heart surgery. Therefore, it is necessary to observe the decrease in hemoglobin levels for prevention and treatment if the decrease exceeds normal.

\section{References}

1. World Health Organization. Cardiovascular diseases. 2017 [cited 2019 Mar 3]. Available from: https://www.who.int/healthtopics/cardiovascular-diseases\#tab=tab_1

2. Weisse AB. Cardiac surgery: a century of progress. Tex Heart Inst J. 2011;38(5):48690.

3. Hessel EA. History of cardiopulmonary bypass (CPB). Best Pract Res Clin Anaesthesiol. 2015;29(2):99-111.

4. Melly L, Torregrossa G, Lee T, Jansens JL, Puskas JD. Fifty years of coronary artery bypass grafting. J Thorac Dis. 2018;10(3):1960-7.

5. Samiei N, Hakimi MR, Mirmesdagh Y, Peighambari MM, Alizadeh-Ghavidel A, Hosseini S. Surgical outcomes of heart valves replacement: a study of tertiary specialied cardiac center. ARYA Atheroscler. 2014;10(5):233-7.

6. Hwang NC. Preventive strategies for minimizing hemodilution in the cardiac surgery patient during cardiopulmonary bypass. J Cardiothorac Vasc Anesth. 2015;29(6):1663-71.

7. Mak MA, Smołka A, Kowalski J, Kuc A, Klausa F, Kremens K, et al. Can cardiopulmonary bypass system with blood priming become a new standard in coronary surgery? Kardiol Pol. 2016;74(8):726-32.

8. BarcelliniW,Fattizzo B.Clinicalapplications of hemolytic markers in the differential diagnosis and management of hemolytic anemia. Dis Markers. 2015;2015:635670.

9. Passaroni AC, de Moraes Silva MA, Yoshida WB. Cardiopulmonary bypass: development of John Gibbon's heartlung machine. Rev Bras Cir Cardiovasc . $2015 ; 30(2): 235-45$.

10. Vermeulen Windsant IC, Hanssen SJ, Buurman WA, Jacobs MJ. Cardiovascular surgery and organ damage: time to reconsider the role of hemolysis. J Thorac Cardiovasc Surg. 2011;142(1):1-11.

11. Passaroni AC, Felicio ML, de Campos NLKL, Silva MA de M, Yoshida WB. Hemolysis and inflammatory response to extracorporeal circulation during on-pump CABG: comparison between roller and centrifugal pump systems. Braz J Cardiovasc Surg. 2018;33(1):64-71.

12. Goksedef D, Omeroglu SN, Balkanay 00, Yalvac ESD, Talas Z, Albayrak A, et al. Hemolysis at different vacuum levels during vacuum-assisted venous drainage: A prospective randomized clinical trial. Thorac Cardiovasc Surg. 2012;60(4):2628.

13. Widyapuspita O, Boom CE. Manajemen transfusi perioperatif pada pasien bedah jantung dewasa dengan mesin pintas jantung paru. JAI (Jurnal Anestesiologi Indones. 2016;8(3):188-205.

14. Keohane EM, Smith LJ, Walenga JM. Rodak's hematology: clinical principles and applications. 5th ed. St. Louis: Elsevier; 2016.

15. Bots SH, Peters SAE, Woodward M. Sex differences in coronary heart disease and stroke mortality: a global assessment of the effect of ageing between 1980 and 2010 . BMJ Glob Health. 2017;2(2):e000298.

16. Spence JD, Pilote L. Importance of sex and gender in atherosclerosis and cardiovascular disease. Atherosclerosis. 2015;241(1):208-10.

17. Vakamudi S, Wu Y, Jellis C, Mick S, Gillinov A, Mihalijevic T, et al. Gender differences in the etiology of mitral valve disease. J Am Coll Cardiol. 2017;69(11 Suppl):1972.

18. BiroKomunikasi danPelayanan Masyarakat Kementrian Kesehatan Republik Indonesia. Penyakit jantung penyebab kematian tertinggi, kemenkes ingatkan CERDIK. 2017 [cited 2019 Dec 27]. Available from: http://sehatnegeriku.kemkes.go.id/baca/ umum/20170801/2521890/penyakitjantung-penyebab-kematian-tertinggikemenkes-ingatkan-cerdik-2/

19. Aftabuddin M, Rajbhandhari N, Rahman MZ, Islam N, Khan OS. Cardiopulmonary bypass induced hematological changes in patients undergoing cardiac surgery. Bangladesh Heart J. 2015;30(2):53-7.

20. Müller MM, Geisen C, Zacharowski K, Tonn T, Seifried E. Transfusion von erythrozytenkonzentraten: indikationen, trigger und nebenwirkungen. Dtsch Arztebl Int. 2015;112(29-30):507-18. 